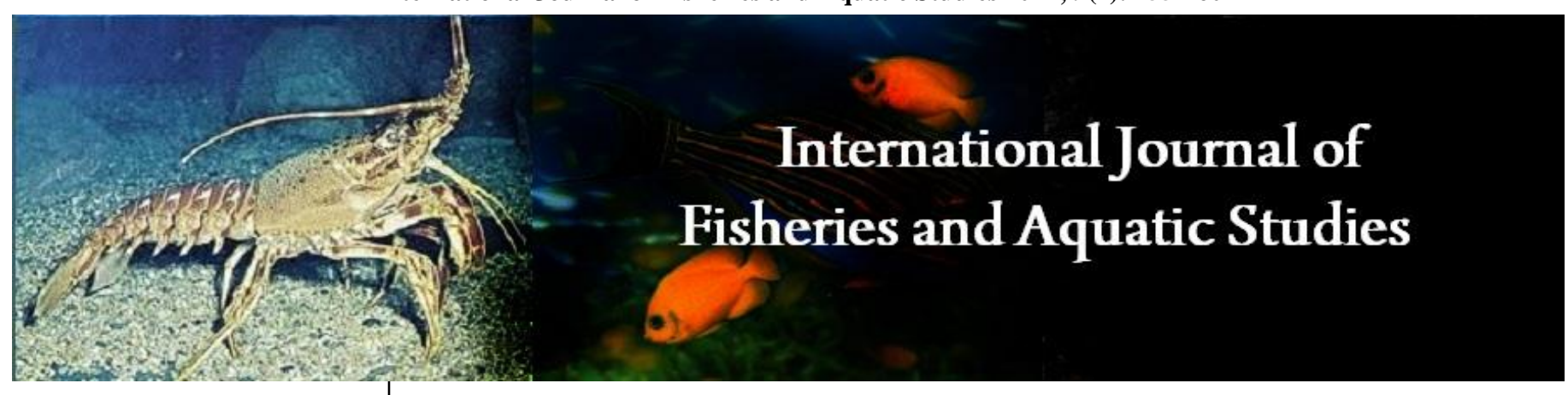

E-ISSN: 2347-5129

P-ISSN: 2394-0506

(ICV-Poland) Impact Value: 5.62

(GIF) Impact Factor: 0.549

IJFAS 2021; 9(2): 255-260

(C) 2021 IJFAS

www.fisheriesjournal.com

Received: 13-01-2021

Accepted: 15-02-2021

Pankaj Jyoti Hazarika

Asstt. Professor, Department of

Economics Sibsagar Commerce

College, Sivasagar Assam, India

Corresponding Author: Pankaj Jyoti Hazarika

Asstt. Professor, Department of Economics Sibsagar Commerce College, Sivasagar Assam, India

\section{Flood is blessing for fish production in natural fisheries: An explorative study in the fishermen of Brahmaputra and Barak valley of Assam}

\section{Pankaj Jyoti Hazarika}

DOI: https://doi.org/10.22271/fish.2021.v9.i2d.2461

\begin{abstract}
Floods are a very regular phenomenon in Assam annually. The state gets a lot of downpour in the rainy season. Subsequently every one of the enormous water ways, beels, low lying zones and lakes are loaded up with water. Flood is a fundamental for fish creation in the natural fisheries in Assam. The fisheries of Assam get covered in the government authorized Natural River and Beel fisheries of Sivasagar, Nagaon and Cachar locale of Assam. The three regions are chosen based on geographical set up, huge quantities of enrolled fisheries and huge measures of income and homogenous nature of fishermen. Fisheries are a very good source of employment for the rural people of Assam. The only money needed in this system is in fish activities, not for increasing the fish production fairs greatly without intervention. Moreover, cooperative groups, NGOs, self help groups are thought to be prominent helpers of the fishing community. Also, flood seems to be a blessing for Assam's fish production. The aim of the paper is to inspect the main drivers of expanding fish profitability in the regular fisheries in Brahmaputra and Barak valley during the time of flood in the state and the study the government measures for increasing fish productivity in the state. The paper also aims to find out how much impact can government measures generate in the enhance system of fish production in the state and how effective can it be. Therefore, the study is explorative in nature.
\end{abstract}

Keywords: flood, natural fisheries, fishermen, co-operative societies, NGOs, self help groups

\section{Introduction}

Floods are rather frequent in Assam. The state gets plenty of rain in the rainy season. As a result all the big rivers, beels, low lying areas and ponds are filled with water. At times up high above the normal level, overflows the banks and submerges the area all around. Assam is the land of two mighty rivers Brahmaputra and Barak. Every year the two rivers, beels and their tributaries cause floods in vast areas of Assam which leads to human misery and devastation of nature.

Fisheries of Assam are also classified in to captured and cultured types. The captured fisheries are rivers, tributaries, beels, low lying areas ponds and tanks. Through the flood harms the significant numbers of population in the state rather the flood is an essential aspect for fish production in the fishermen of the natural fisheries. The paper examines the root causes of increasing fish productivity in the natural fisheries in the both valley during the period of flood in the state.

The state of Assam, scheduled caste and minority Muslims communities are playing dominant role in fishing sector. In Brahmaputra valley most of the kaibratta people under the scheduled caste community are involved in the fishing activities and in Barak valley the minority Muslim (mimal community) origin from Bangladesh is also involved in this sector. Fishing is the main occupation or livelihood of these communities.

\subsection{Objectives}

i. To examine the impact of flood on fish production in the natural fisheries of the study area.

ii. To study the government functions for increasing fish productivity during the flood in the natural registered fisheries. 


\subsection{Hypothesis}

Ho-Null Hypothesis: There is no association between the districts/fishermen and fish production in the natural fisheries during the period of flood.

$\mathrm{H}_{1^{-}}$Hypothesis: There is association between the districts/fishermen and fish production in the natural fisheries during the period of flood.

\subsection{Methodology}

The study is explorative in nature.

\subsubsection{Source of Data Collection}

Both primary and secondary sources of data are used in this study. The primary data has been personally collected from the selective sample registered fisheries (river and beel) which is run by the fisheries co-operative societies; self-help groups and non government organization. The persons who are the actual fishermen/shareholder of different strata involved in this sector. The secondary data has been collected from various sources, such as reports from the fishery department of the State Government of Assam, district gazetteer, census report, official records, newspapers, journals and various websites.

\subsubsection{Universe of the Study}

The fisheries cover in the government registered Natural River and Beel fisheries of Sivasagar, Nagaon and Cachar districts of Assam. The three districts are selected on the basis of geographical set up, huge numbers of registered fisheries and the amount of revenue (collected from the registered fisheries) and homogenous nature of the fishermen.

The Sivasagar district represents in the upper part of the Brahmaputra Valley state. It has 32 numbers of registered fisheries .The Nagaon district covers the middle part of the state. It has also 52 nos.of fisheries and both districts of the state represent from the Brahmaputra valley.

The Cachar district covers the Barak valley of the state. The district has highest numbers (81nos.) of registered fisheries and from the three districts the state government is able to collect a good amount of revenue than the nearest districts of their own zone. (Department of fishery Government of Assam)

\subsubsection{Sample Size}

The total registered fisheries in the study area are 162. These registered fisheries are run by the fisheries co-operative societies, self help groups and non government organization in the full supervision of the fishery department of the state government of Assam. Out of this number, 30\% fisheries have been selected on the basis of random sampling for field observation and data collection in depth study. These 30\% registered fisheries have 1373 shareholders or fishermen and from these number again 30\% share holder or fishermen i.e.415 (Sivasagar-159,Nagaon-111 and Cachar-145) are taken which is closely involved in the sample fisheries that have been interviewed from the sample districts of the state.

\subsubsection{Tools and techniques}

The quesionarrie and personal interview with the respondents is the main tool of the study. After collecting, the data is properly classified, processed, tabulated, with the help of statistical tool like percentage, bar diagrams, chi square test etc.

\section{Analysis}

The study examines the several natural registered fisheries and their shareholders in both valley Brahmaputra and Barak. From the study it is able to examine the effect of flood on fish production in natural fisheries. The selected registered fisheries and their co-operative societies, self help groups and non government organizations are given in the following table where the utility of the fishery sector in the state economy has been analyzed.

Table 1: Natural registered fisheries and utility of the state economy (District-Wise in both Valley Brahmaputra \& Barak in Assam)

\begin{tabular}{|c|c|c|c|c|c|c|}
\hline $\begin{array}{l}\text { Sl. } \\
\text { No }\end{array}$ & $\begin{array}{l}\text { Name of the } \\
\text { fisheries }\end{array}$ & $\begin{array}{l}\text { Nature } \\
\text { of the } \\
\text { fisheries }\end{array}$ & Cooperative soc./SHG/NGO & District & Tenure & $\begin{array}{c}\text { Amount of } \\
\text { Revenue(yearly) }\end{array}$ \\
\hline 1 & Brahmaputra Part-1 & $\begin{array}{l}\text { River } \\
\text { fishery }\end{array}$ & $\begin{array}{c}\text { Brahmaputra } \\
\text { Part-1meen Samabai Samittee } \\
\text { (Cooperative society) }\end{array}$ & Sivasagar & $2010-17$ & 47,520 \\
\hline 2 & Brahmaputra Part-2 & do & Row mari Phukan fadia SHG & do & $2018-22$ & $12,05,000$ \\
\hline 3 & Dikhow Part-2 & do & Dikhow meen Samabai Samittee & do & $2016-19$ & 1,00550 \\
\hline 4 & Diroy & do & Kamal Das & do & $2015-20$ & $1,13,000$ \\
\hline$\frac{T}{5}$ & Dishang Part-1 & & Rajib Das & do & $2016-22$ & 32,000 \\
\hline 6 & Dishang Part-2 & do & Dishang part 2 meen samabai samittee & do & $2009-16$ & $4,20,000$ \\
\hline 7 & Demow & do & Dishang meen Samabai Samitee & do & $2012-18$ & $4,51,000$ \\
\hline 8 & Dorika Part -2 & do & $\begin{array}{l}\text { Dighali bhagamur meen samabai } \\
\text { samittee }\end{array}$ & do & $2015-22$ & $1,77,303$ \\
\hline 9 & Dorika Part-3 & do & Row mari Phukan fadia SHG & do & $2019-2026$ & $1,51,000$ \\
\hline 10 & Teliadunga & & SHG(Babul Das) & do & $2014-2020$ & $6,50,000$ \\
\hline 11 & Mori Dikhow & beel & NGO & do & & 101000 \\
\hline 12 & Panikhati & do & SHG & do & per year & 40,000 \\
\hline 13 & Borchola & do & SHG, Garbhaga (TMPK) & do & per year & 400,000 \\
\hline 14 & Mornoi panikhati & & Bhagamur meen samabai samittee & do & $2015-22$ & 26501 \\
\hline \multirow{4}{*}{15} & \multirow{4}{*}{ Jia Mitong } & \multirow{4}{*}{ do } & Rekibuddin Ali & do & 2014- 2015 & 100,000 \\
\hline & & & Tupidhar Das & do & $2015-2016$ & $1,70,000$ \\
\hline & & & Kumolia Ali & do & $2016-2017$ & 192,000 \\
\hline & & & Dilip Hazarika and group & do & $2017-2018$ & 233570 \\
\hline 16 & Borgila & do & $\begin{array}{l}\text { Anup Phukan } \\
\text { Kumud Konwar } \\
\text { Kumud Konwar }\end{array}$ & do & $\begin{array}{l}2014-2015 \\
2015-2016 \\
2016-2018\end{array}$ & $\begin{array}{c}150000 \\
199000 \\
215000 \text { (per yr) }\end{array}$ \\
\hline
\end{tabular}




\begin{tabular}{|c|c|c|c|c|c|c|}
\hline 17 & Dighali Bhagamur & do & Secy.Digheli Bhangamur Min SSL & do & $\begin{array}{l}2012-1013 \text { to } \\
2018-19\end{array}$ & $101,000 /$ \\
\hline 18 & Moridisang & do & Secy. Dhigali Singra MSS Ltd & do & $\begin{array}{l}2012-13 \text { to } \\
2018-19\end{array}$ & $53000 /$ \\
\hline 19 & Fulai Dighali & do & Secy. Dhigali Singra MSS Ltd & do & $\begin{array}{l}2015-16 \text { to } \\
2021-22\end{array}$ & $56000 /$ \\
\hline 20 & Erakapili (Nagaon) & beel & Secy.23 Borpani \& 58 laopani SS Ltd. & Nagaon & $\begin{array}{l}2015-16- \\
2021-22\end{array}$ & \\
\hline 21 & Fulai Dighali & do & $\begin{array}{l}\text { Secy. Dighali chgia Matchya Samabai } \\
\text { Samittee Ltd. }\end{array}$ & do & $2016-17$ & 42251 \\
\hline 22 & Dighali Bhangamur & do & $\begin{array}{l}\text { Secy.Dighali Bhangamur Meen } \\
\text { Samabai Samittee }\end{array}$ & do & $2016-17$ & 145101 \\
\hline 23 & Dighali Singorajan & do & Secy.Dighali Singarajan Matchya SSL & do & $2016-17$ & 151000 \\
\hline 24 & 68 No.Haribhanga & do & Secy.68no Haribhanga fishery SSL & do & 2016 & 109800 \\
\hline 25 & No.6 Barak River & River & $\begin{array}{c}\text { Central Silchar Fishery Co-op Society } \\
\text { Ltd, Hathicherra ,Silchar }\end{array}$ & Cachar & $\begin{array}{l}1-12-12 \text { to } \\
30.11 .2019\end{array}$ & $2,52,080$ \\
\hline 26 & No.7 Barak River & do & $\begin{array}{l}\text { East ktg. Fishery Cop.Soc, } \\
\text { Fulbari,Cachar }\end{array}$ & do & $\begin{array}{l}\text { 8.9.2012 to } \\
7.9 .2019\end{array}$ & $3,10,601$ \\
\hline 27 & No.9.Borak River & do & Sunrise SHG,Panchgram & do & $\begin{array}{l}\text { 1.5.2014 to } \\
30.4 .21\end{array}$ & $4,55,000$ \\
\hline 28 & No 10 Barak River & do & $\begin{array}{c}\text { Fish farmer SHG, } \\
\text { Chandinagar,Harinagar }\end{array}$ & do & $\begin{array}{l}1.9 .2010 \text { to } \\
19.12 .2015\end{array}$ & $19,01,907$ \\
\hline 29 & $\begin{array}{l}\text { No.12 and No.13 } \\
\text { Surma River River }\end{array}$ & do & Tomjid Ali NGO & do & $\begin{array}{l}\text { 1-4-2014 to31.3.2021 } \\
\text { do }\end{array}$ & $\begin{array}{l}65,500 \\
43,500\end{array}$ \\
\hline 30 & No.16Ghagra River & do & Moinul and others & do & $\begin{array}{c}1-12- \\
\text { 2014to31.12.2021 }\end{array}$ & 97,650 \\
\hline 31 & $\begin{array}{l}\text { No.33 Bollessar } \\
\text { River }\end{array}$ & do & $\begin{array}{c}\text { North Katigorah Fishery Cop.Society } \\
\text { Ltd.Mohadevpur }\end{array}$ & do & $\begin{array}{l}1.10 .2013 \text { to } \\
30.09 .2020\end{array}$ & $2,48,200$ \\
\hline 32 & Jatinga River & do & NGo & do & $\begin{array}{l}\text { 10.5.2012 to } \\
30.4 .2019\end{array}$ & $1,31,800$ \\
\hline 33 & $\begin{array}{l}\text { No.11Kushiara } \\
\text { River }\end{array}$ & do & Kushiar River Fishery MSS & do & $\begin{array}{l}1.9 .2010 \text { to } \\
19.12 .2015\end{array}$ & $3,71,500$ \\
\hline 34 & No.12Surma River & do & Surma SHG & do & $\begin{array}{l}1.4 .2014 \text { to } \\
31.3 .2021 \\
\end{array}$ & $7,57,000$ \\
\hline 35 & No.12Surma River & do & do & do & $\begin{array}{l}1.4 .2014 \text { to } \\
31.3 .2021 \\
\end{array}$ & $5,05,000$ \\
\hline 36 & No.14 Sonai River & do & Sonai fishery SSL & do & $\begin{array}{l}\text { 15.7.2011to } \\
14.7 .2016\end{array}$ & 62,775 \\
\hline 37 & $\begin{array}{l}\text { No } 24 \text { Borkhangali } \\
\text { Beel }\end{array}$ & do & $\begin{array}{l}\text { North Katigorah FisheryCop.Society } \\
\text { Ltd.Mohadevpur }\end{array}$ & do & $\begin{array}{l}30.6 .2012 \text { to } \\
30.6 .2016\end{array}$ & 26,540 \\
\hline 38 & $\begin{array}{c}\text { No.34 Talkar Beel } \\
\text { Fishery }\end{array}$ & do & Shib Shambu SHG, Mohadebpur & do & $\begin{array}{l}\text { 1.10.2011 to } \\
30.9 .2018\end{array}$ & $5,73,107$ \\
\hline 39 & $\begin{array}{c}\text { No.52 Buraraiya } \\
\text { Beel }\end{array}$ & do & Sonali SHG,Bhangarpar & do & $\begin{array}{c}\text { 15.7.2011 to } \\
31.3 .2014 \\
\text { (Sub Judice) }\end{array}$ & 5.33000 \\
\hline 40 & $\begin{array}{l}\text { No.53 Kharuamara } \\
\text { Beel }\end{array}$ & do & $\begin{array}{l}\text { North Katigorah Fishery Cop.Society } \\
\text { Ltd.Mohadevpur }\end{array}$ & do & $\begin{array}{c}15.08 .2011 \text { to } \\
14.8 .2016\end{array}$ & 3,65000 \\
\hline 41 & $\begin{array}{c}\text { No.56/64 } \\
\text { Moichartol } \\
\text { Sundorkuri Beel }\end{array}$ & & $\begin{array}{c}\text { East Katigorah Fishery Cop.Society } \\
\text { Ltd.Sripur }\end{array}$ & do & $\begin{array}{l}1.3 .2012 \text { to } \\
28.2 .2019\end{array}$ & $6,63,000$ \\
\hline 42 & No.57 Roa Beel & & NGO & do & $\begin{array}{l}1.5 .2011 \text { to } \\
30.4 .2015\end{array}$ & $1,19,655$ \\
\hline 43 & No.71 Punikhal & & NGO & do & $\begin{array}{l}1.9 .2011 \text { to } \\
31.8 .2016\end{array}$ & $1,35,001$ \\
\hline 44 & Barsugati & do & Pachgram MSS & do & $2016-17$ & 61,000 \\
\hline 45 & Berakhal & do & SHGS & do & $2016-17$ & $2,11,101$ \\
\hline 46 & No.31 Korkori Beel & & Korkori beel SHG & do & $\begin{array}{l}1.8 .2011 \text { to } \\
30.7 .2016\end{array}$ & $1,88,000$ \\
\hline 47 & Son Beel & do & Son beel fishery S.S.Ltd. & do & $2016-17$ & 1100000 \\
\hline 48 & No.40 Amjur Nodi & do & Sunahor Ali and others & do & 2011 to 2016 & 557,00 \\
\hline
\end{tabular}

Source: Office report of Deputy Commissioner (Revenue Branch), Sivasagar,Nagaon and Cachar District

Report of Fishery Development Corporation Guwahati 2016-17

In the above table it is seen that these natural registered fisheries have been playing a significant role to the state economy. Most of the fishermen get livelihood from these registered fisheries. These fisheries are run by different fisheries co-operative societies, self help groups and Non government organizations. These fisheries co-operative societies, self help group and non Government Organization are the organization of the shareholders/members of the 
scheduled caste community in Brahmaputra valley and Mimal community in the Barak Valley. Because according to the State Government fisheries management rule only the hundred percent fishermen (certified by district fishery department) of the scheduled caste and mimal communities are eligible to run these fisheries. So as fishing community the fishermen of the both communities are able to get the opportunity for upliftment their socio-economic status of the state.

In the table it is found that the satisfactory amount of revenue has been able to give to the state government by the fisheries co-operative societies, self help groups and non government organization of the registered fisheries which is considered as blessing for the state economy. After completing the lease period of fishery the state government increases $10 \%$ revenue for the coming lease period in the every registered fisheries.
The registered fisheries are able to give for increasing amount of revenue to the state government of Assam due to enhancement of quantity of fish production and the raising the price of fish in the market. It has been possible for coming frequent flood in the natural fisheries of the state.

Getting various opinions from the fishermen of the above mentioned registered fisheries in the study area it reveals that the flood is blessing for fish production. When the flood rise more and frequently, then the quantity of fish population increases and when the flood does not come frequently during the seasons then the fish production does not rise in the natural beel and river fisheries.

The following table shows the opinion of the fishermen on the increasing fish productivity during the flood in the natural fisheries of the study area.

Table 2: Flood is blessing for fish production (opinion of the respondents in district wise)

\begin{tabular}{|c|c|c|c|c|c|c|}
\hline Sl No & Name of the Districts & Yes (agree) & $\boldsymbol{\%}$ & No (Not agree) & $\%$ & $\%$ \\
\hline 1 & Sivasagar & 151 & 94.97 & 08 & 5.03 & 100 \\
\hline 2 & Nagaon & 106 & 95.49 & 05 & 4.51 & 100 \\
\hline 3 & Cachar & 128 & 88.27 & 17 & 11.73 & 100 \\
\hline Total & & 385 & 92.53 & 31 & 7.47 & 100 \\
\hline
\end{tabular}

Source: Primary Survey

From the table it is seen that the 92.77 percent respondents agree that flood is blessing for fish production. The district wise opinion of the fishermen i.e. 94.97 percent respondent in Sivasagar district, 95.49 percent respondent in Nagaon district and 88.27 percent respondent in Cachar district agree in favour of fish production in these natural fisheries.

According to the fishermen of the study area -

- The rain starts from March and end at last of September in the state. During this period new water covers in the all low lying areas and natural water bodies while the flood begins. At that time, the fish can play freely in the new floating water and they get opportunity for breeding.

- During the period of flood some different species of fish migrate from different rivers, tributaries and other water bodies in various states and countries which help in an increase the production of fish in the natural fisheries.

- The state government of Assam implemented a strict role on the fishermen and the fisheries co-operative societies, self-help groups and non-government organizations for not fishing in the time of breeding period in the river and beel fisheries. Sometime the fishery department provides some financial support to the fishermen for prevent fishing at the time of breeding and at the same time the State Government helps to the fishermen of the Cooperative Societies, Self Help Groups and Non Government Organization to organize some awareness program for increasing the fish production in the natural fisheries. That is why the fishermen and the different registered fishing organization does not fishing in these fisheries and ultimately the fish production get increase in the time of flood.

- The fishermen of the Co-operative Societies, SHG's and
NGO's are aware on the actual breeding time of fish during the period of flood in the state. Before the year of 2005 (fish seed act 2005 was launched) majority of the Co-operative Societies, SHG's and NGO's kept brood fish through obstruction the floating river by using big net in the time of breeding when the new water covers (during flood) in the rivers and beels. Then much quantity of brood fish was kept. At present, many of the shareholders (fishermen) in the Co-operative societies, SHG's and NGO's are aware about the government regulation of fishing in the breeding period of fish. They prevent the earlier fishing methods. Therefore fish can get more opportunities for breeding in the water bodies and as a result the population of fish increases.

On the basis of the opinion of the fishermen mentioned in the above table it is statistically examined. As a statistical tool the chi square test has been done in the following.

\section{Chi-Square Test}

\begin{tabular}{|c|c|c|c|}
\hline & Value & df & Asymp. Sig. (2-sided) \\
\hline Pearson Chi-Square & $22.636^{\mathrm{a}}$ & 2 & .000 \\
\hline
\end{tabular}

0 cells $(.0 \%)$ have expected count less than 5 .

Since the P- Value is less than 0.05 , the null hypothesis may be rejected. Thus according to the Chi-Square test, there is association between the districts and fish production. So, from the study it is found that the flood is blessing for fish production in the fishermen of the natural fisheries in the state.

In the following bar chart the opinion of the fishermen in the district-wise has been shown. 


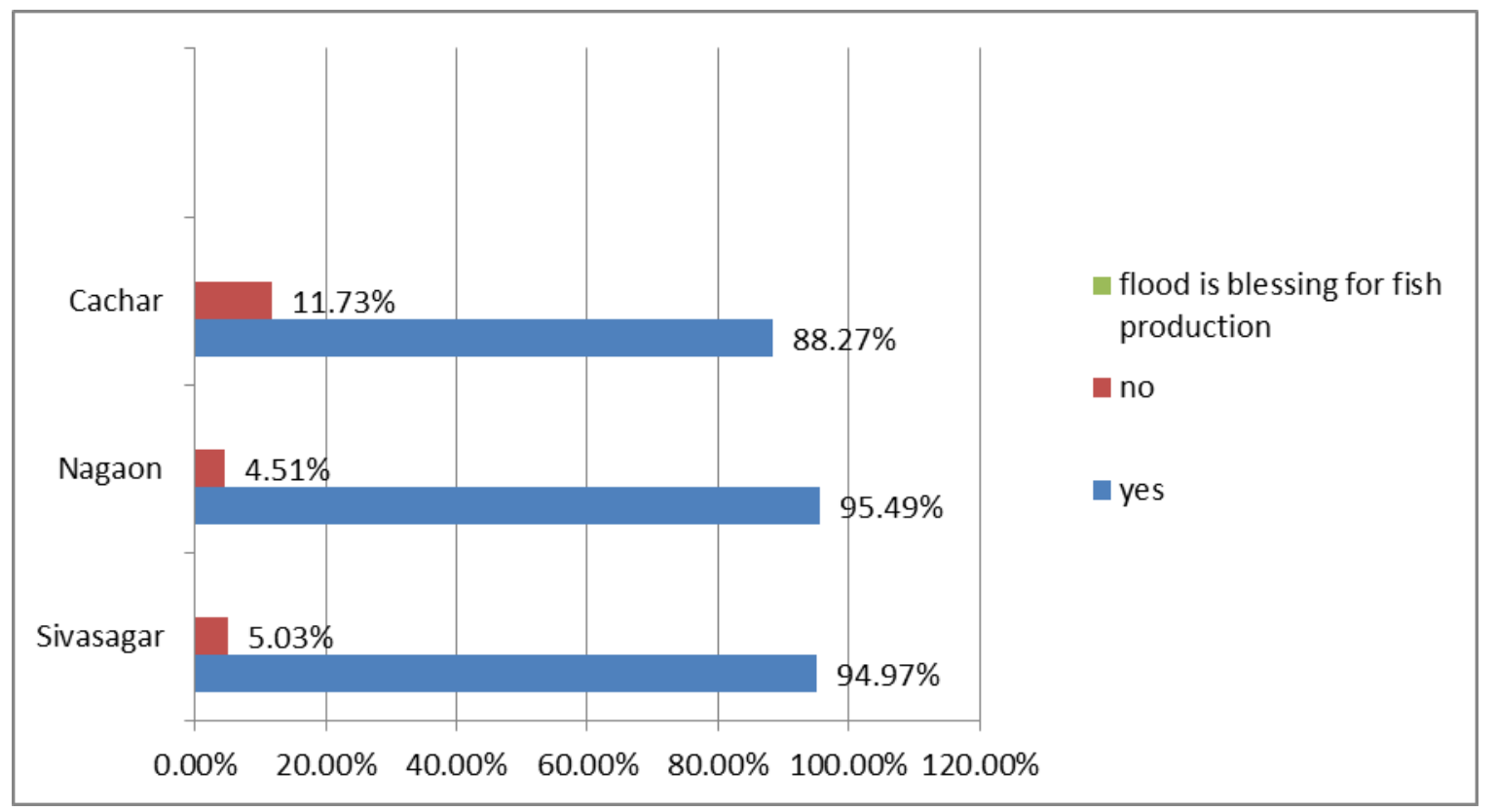

Fig 1: In the following bar chart the opinion of the fishermen in the district-wise has been shown

\section{Findings of the Study}

The main findings of the study are:

i. Most of the registered river and beel fisheries of the both valley in the state of Assam provide a good opportunity of employment because a significant numbers of youth fishers are able to involve in the fishery sector. On the other hand the state government of Assam gets a satisfactory amount of revenue from the fisheries.

ii. In the study it is found that no investment is required for increasing the fish productivity in natural fisheries because fish productivity is natural process of the natural fisheries. Therefore the fisheries co-operative societies, self help group and non government organization need not spend for fish productivity. They spend on the fishing activities.

iii. Another important major finding of the study is that the state government fishery department, co-operative societies, self-help group and NGO play an important role for observing the fish productivity during the period of flood. Mainly in Assam the flood starts from April to September, during the period the state government fishery department do not allow for fishing in three months from $31^{\text {st }}$ March to June due to high breeding time of fish. Therefore fish production increases in the natural fisheries in the period

iv. In the study it is found that the null hypothesis is rejected because the significant level is less than 0.05.According to the Chi-Square test, there is association between the districts and fish production. So, the study reveals that the flood is blessing for fish production in the fishermen of the natural fisheries in the state.

v. One of the major findings of the study is that the state government fishery department implemented fish seed act 2005.The main aim of the act is protect the brood fish in the breeding time. For the existence of the act the fishermen of the fisheries co-operative societies, self help group and non government organization cannot catch the fish in the river and beel fisheries.

vi. Another important result is found that the state government takes a positive step for helping the fishermen in the registered fisheries during the ban period of fishing. Besides the fishery department of the state government organize some awareness programme regarding the fish productivity in the natural fisheries in Assam.

\section{Suggestions \& Conclusion}

i. The fishery department of state government should take preventive step for not fishing in the period of flood because during the period the fish moves among the many rivers and bells. In this time the fish gets new floating water. Therefore the authority should go for checking the place frequently.

ii. The state government should provide financial support to the fishermen of the registered fisheries during the ban period of fishing.

i. The state government should relax the amount of revenue to the registered fisheries during the ban period of fishing then the registered fisheries will get financial support and they will take necessary step against the fishing in the period of flood.

ii. The fishery department government of Assam has to involve some NGO,s for creating awareness among the fishermen in the state.

From the study it is sure that the natural fishery has great prospective sector in the rural economy of the both valley in the state. Frequent flood brings the environment of fish production in these fisheries. The rural people of the scheduled caste and mimal community in the state are able to get employment opportunity from this sector which considered as blessing for the economy. In this study it is seen that most of the fishermen support that flood is positive aspect for fish productivity in the natural fisheries.

\section{References}

1. Bora Chetia B, Bania R. Carp Seed Production in NE India. Assam Agricultural University, Jorhat 2018.

2. Bora Chetia, Bhattacharyya HC. Strategy for Developing Fisheries in Flood affected areas of Assam. (Eds) Assam Agricultural University, Jorhat 2013.

3. Das. Fish Seed Industry in Assam, publ. College of Fisheries, Assam Agriculture University, Raha, Nagaon 2000. 
4. Hazarika BK. Core problems of scheduled caste of Assam, Assam Institute of Research for S.T and S.C, Guwahati 1995.

5. Kalita K. Problem and Prospect of aqua farming in Assam, College of Fisheries, Assam Agriculture University, Raha, Nagaon 2006.

6. Pathak SC. Institutional credit support for fish seed Development in North-East Region, Publ. College of Fisheries, Assam Agriculture University, Raha, Nagaon. Planning Commission, Govt. of India 2000.

7. John Kurien. Socio-economic Conditions of Traditional Fishermen, CMFRI Bulletin 1981;30:35-53.

8. Rajbangshi, Kumar Manoj et al. Current Status of fish Diversity of Kamandanga Beel of Kokrajhar District, Assam India, International Journal of Plant, Animal And environmental Science 2016, 7.

9. Assam Statistical Handbook.(2009-10, 2010-2011, 201112). Publ. Assam Statistical Department, Assam.

10. Department of Fishery Report. (2016-17).Govt. of Assam.

11. The Economic Survey of Assam (2015-16).

12. Fish seed act of Assam (2005)

13. Internet:

14. https://www.telegraphindia.com/north-east/54-increasein-fish-production-in-assam/cid/1426236

15. https:// des.assam.gov.in/ sites/ default/ files /swf utility_ folder/ departments/ ecostat _medhassu _in_oid_3/ this_comm/ Statistical\% 20 Hand $\% 20$ Book $\% 20$ Assam\%2C $\% 202012$.pdf

16. http://ijiset.com/vol2/v2s1/IJISET_V2_I1_77.pdf

17. https://www.telegraphindia.com/north-east/54-increasein-fish-production-in-assam/cid/1426236 